\title{
THE DIVERSE AND HETEROGENEOUS CLINICAL FEATURES OF JUVENILE PSORIATIC ARTHRITIS
}

Svetlana Nikolaevna Chebysheva ${ }^{1 *}$, Elena Spartakovna Zholobova ${ }^{1}$, Natalya Anatolevna Geppe ${ }^{1}$, Karina Vladimirovna Aleksanyan ${ }^{1}$, Angelina Valerevna Meleshkina ${ }^{1}$, Khitrov Alexandr Nikolaevich ${ }^{2}$, Saltykov Alexandr Borisovich ${ }^{2}$, Tachieva Bella Isaevna ${ }^{2}$, Vorobyev Sergey Ivanovich ${ }^{3}$, Bolevich Stefani Sergeevna ${ }^{2}$ and Bolevich Sergey Brankovich ${ }^{2}$

${ }^{l}$ Filatov Institute of Childhood Clinical Health, Department of Childhood Diseases, Sechenov University, I.M. Sechenov First Moscow State Medical University (Sechenov University), Moscow, Russian Federation

${ }^{2}$ Department of Human Pathology, Sechenov University, I.M. Sechenov First Moscow State Medical University (Sechenov University), Moscow, Russian Federation

${ }^{3}$ Federal State Autonomous Educational Institution of Higher Education I.M. Sechenov First Moscow State Medical University of the Ministry of Health of the Russian Federation, Sechenov University, Russia

\section{VARIJABILITET I HETEROGENOST KLINICKIH MANIFESTACIJA JUVENILNOG PSORIJATICNOG ARTRITISA}

Svetlana Nikolaevna Chebysheva ${ }^{1 *}$, Elena Spartakovna Zholobova ${ }^{1}$, Natalya Anatolevna Geppe ${ }^{1}$, Karina Vladimirovna Aleksanyan ${ }^{1}$, Angelina Valerevna Meleshkina ${ }^{1}$, Khitrov Alexandr Nikolaevich², Saltykov Alexandr Borisovich², Tachieva Bella Isaevna ${ }^{2}$, Vorobyev Sergey Ivanovich ${ }^{3}$, Bolevich Stefani Sergeevna ${ }^{2}$ and Bolevich Sergey Brankovich ${ }^{2}$

${ }^{1}$ Filatov Institut za zdravlje omladine, Odeljenje za dečje bolesti, Univerzitet Sečenov, Prvi moskovski državni medicinski univerzitet, Moskva, Ruska Federacija

${ }^{2}$ Katedra za humanu patologiju, Univerzitet Sečenov, Prvi moskovski državni medicinski univerzitet, Moskva, Ruska Federacija

${ }^{3}$ Federalna državna autonomna obrazovna ustanova visokog obrazovanja I.M. Sechenov Prvi moskovski državni medicinski univerzitet Ministarstva zdravlja, Moskva, Ruska federacija

\begin{abstract}
Juvenile Psoriatic Arthritis (JPSA) is a chronic inflammatory disorder that accounts for 3-10\% of all juvenile arthritis. The main objective is to identify the clinical features of psoriatic arthritis in children. This study was open-label, single-center, prospective, observational (1989-2020) cohort clinical study included 85 patients (3-17.0 y/o) who met Vancouver and I/E criteria. The features of skin and articular syndromes in children with $J P S A$ were revealed. In most patients with PSA, the disease began at the age of 6.6 years. In childhood, arthritis is usually preceded by psoriasis. The most common clinical form of psoriasis is plaque psoriasis. At the onset of the disease, symmetric polyarthritis predominates. During the disease, transformation of the joint syndrome with a predominance of rheumatoid arthritis is noted. All observed patients showed pronounced osteoporosis, which is not characteristic of JPSA.
\end{abstract}

Keywords: Vancouver diagnostic criteria, psoriasis, juvenile psoriatic arthritis, juvenile idiopathic arthritis.

\section{SAŽETAK}

Juvenilni psorijatični artritis (JPSA) je hronični inflamatorni poremećaj koji čini 3-10\% svih juvenilnih artritisa. Glavni cilj je da se identifikuju kliničke karakteristike psorijatičnog artritisa kod dece. Ova studija je bila otvorena, jednocentrična, prospektivna, opservaciona (1989-2020) kohortna klinička studija uključivala je 85 pacijenata (3-17,0 godina) koji su ispunjavali Vankuverske i I/E kriterijume. Otkrivene su karakteristike kožnih $i$ zglobnih sindroma kod dece sa JPsA. Kod većine pacijenata sa PSA, bolest je počela u dobi od 6,6 godina. U detinjstvu, artritisu obično prethodi psorijaza. Najčešći klinički oblik psorijaze je psorijaza plaka. Na početku bolesti preovlađuje simetrični poliartritis. Tokom bolesti primećuje se transformacija zglobnog sindroma sa prevlašću reumatoidnog artritisa. Svi posmatrani bolesnici su pokazali izraženu osteoporozu, koja nije karakteristična za JPSA.

Ključne reči: Vankuverski dijagnostički kriterijumi, psorijaza, juvenilni psorijatični artritis, juvenilni idiopatski artritis. 


\section{INTRODUCTION}

Psoriatic arthritis (PsA) is a chronic inflammatory joint disease that develops in about a third of patients with psoriasis (1). Juvenile Psoriatic Arthritis (JPsA) is presented in 4 $9 \%$ of children with juvenile arthritis $(2,3)$.

The criteria for the International League of Associations for Rheumatology (ILAR, 2001) and the Vancouver Criteria (1989) are used to diagnose JPsA $(4,5)$.

According to the ILAR criteria, Definite JPsA was defined as arthritis associated with psoriasis, or arthritis and at least 2 of the following: dactylitis, nail pitting or onycholysis, psoriasis in a first-degree relative. Exclusions criteria: arthritis in an HLA-B27 positive male beginning after the 6th birthday; ankylosing spondylitis, enthesitis related arthritis, sacroiliitis with inflammatory bowel disease, Reiter's syndrome, or acute anterior uveitis, or a history of one of these disorders in a first-degree relative; the presence of IgM rheumatoid factor on at least 2 occasions at least 3 months apart; the presence of systemic JIAin the patient (4). Psoriatic arthritis is a form of arthritis that affects some people with psoriasis. Psoriasis is a chronic skin and nail disease characterized by red, scaly rashes and thick, pitted fingernails. About one-third of children with psoriasis will have psoriatic arthritis. Psoriatic arthritis is a form of juvenile idiopathic arthritis (JIA) and is characterized by chronic joint inflammation and swelling, as well as an increased risk for asymptomatic eye inflammation. Psoriatic arthritis accounts for approximately 6 percent of all cases of juvenile arthritis. Although the cause of psoriatic arthritis is unknown, factors such as immunity and the environment may play a role. Genetics also appear to be involved: $40-80$ percent of children with psoriatic arthritis have an affected first- or second- degree family member, such as a sibling, parent, grandparent or aunt/uncle.

Therefore, in pediatric rheumatological practice, the Vancouver criteria are more often used (5). According to Vancouver criteria Definite JPsA is defined as arthritis associated, but not necessarily coincident, with a typical psoriatic rash, or arthritis plus at least 3 of 4 minor criteria: dactylitis, nail pitting, psoriasis-like rash, or family history of psoriasis. Probable JPsA is defined as arthritis plus 2 of the minor criteria.

The clinical picture of JPsA is diverse and heterogeneous. There are no specific laboratory tests. Instrumental methods reflect only the presence and severity of the inflammatory process. JPsA is an interdisciplinary problem and requires the joint supervision of rheumatologists and dermatologists.

The main aim of this study was to identify the clinical features of psoriatic arthritis in children.

\section{METHODS}

\section{Design of study}

This study was open-label, single-center, prospective, observational (1989-2020) cohort clinical study included 85 patients (3-17.0 y/o) who met Vancouver and I/E criteria.

\section{Data collection presentation and follow-up}

Patients' charts were reviewed for the following clinical variables at presentation and at each follow-up visit: height, weight, joint involvement, presence or absence of symmetric arthritis, nail pits, dactylitis, presence of psoriatic rash or psoriasis-like rash, and uveitis. All me- dications, including corticosteroid joint injections, were recorded for each visit. Patient visits at presentation $1,3,6,12,36$, and 60 months following the first presentation and every 5 years thereafter were used. Serologic variables studied were: a) Rheumatoid Factor (RF) as detected by latex agglutination; a positive test result was defined as titer $\geq 2$ on at least two occasions (data were available on $88 \%$ of patients); b) Anti-nuclear antibody (ANA) as detected by immunofluorescent microscopy using the Hep2 cell line. A positive result was defined as a titer $\geq$ $1: 40$ on at least one occasion (data were available on $88 \%$ of patients); and c) HLA B-27 antigen (data were available on $44.5 \%$ of patients).

The following complications were recorded at each visit: presence of a joint contracture, and presence of leg-length discrepancy. The Childhood Health Assessment Questionnaire (CHAQ) (14) was available at last follow-up in 73.1\% of the patients. For patients with uveitis the final visual acuity and ocular complications were obtained (15).

\section{Definitions}

The diagnosis of psoriasis was made by a rheumatologist and/or dermatologist. Rashes thought likely (but not definitively) to represent psoriasis were considered psoriasislike.

Polyarticular involvement was defined by the involvement of $\geq 5$ joints cumulatively at any point over the course of study. Oligoarticular arthritis was defined as involvement of $<5$ joints: a) persistent oligoarthritis- $<5$ joints throughout the disease course; or b)extended- $\geq 5$ were involved at any point after the initial 6 months. Enthesitis was defined as tenderness at a tendinous, ligamentous, capsular, or fascial insertion into bone. Dactylitis was defined as digital swelling extending be- yond the margins of the joints. Patients with dactylitis were not considered to have involvement of the corres-ponding joint(s) with arthritis unless it was specifically documented.

Symmetric arthritis was defined as being present if the number of affected joint pairs divided by the total number of joints involved was $\geq 50 \%$. The fol- lowing 11 joint pairs were used: shoulders, elbows, wrists, any metacarpophalangeal (MCP), any pro- ximal interphalangeal (PIP) of the 
hand, hips, knees, ankles, any metatarsophlangeal (MTP), any PIP) of the foot, and the temporomandibular (TMJ).

\section{Statistic methods}

\section{RESULTS}

In this study we observed 85 patients with JPsA aged from 3 to 17 years. Fifty-nine (70\%) patients had definite JPsA and $24(20 \%)$ had probable JPsA, according to the
All descriptive data were expressed as the mean \pm standard deviation (SD). Comparisons between groups were performed using Chi-Square Tests with Bonferroni correc- tions. All data are presented in form of the Tables and Figures.

Table 1. The clinical and demographic characteristics of patients with JPsA $(n=85)$

\begin{tabular}{|c|c|c|c|}
\hline \multicolumn{2}{|c|}{ Demographic indicators } & \multicolumn{2}{|c|}{ JPsA } \\
\hline & & Definite & Probable \\
\hline \multicolumn{2}{|l|}{ Number of patients (n) } & 60 & 25 \\
\hline \multicolumn{2}{|l|}{ Girl/Boy Ratio } & $1,7: 1$ & $2: 1$ \\
\hline \multicolumn{2}{|l|}{ Average age, years } & $6,6 \pm 4$ & $6,3 \pm 2,7$ \\
\hline \multicolumn{2}{|c|}{ Duration of the disease, years } & \multicolumn{2}{|l|}{$3 \pm 2$} \\
\hline \multirow{2}{*}{$\begin{array}{c}\text { Family } \\
\text { history of } \\
\text { psoriasis n, (\%) }\end{array}$} & $\begin{array}{l}\text { First-degree relative } \\
\text { with } \\
\text { psoriasis }\end{array}$ & \multicolumn{2}{|l|}{$22(26 \%)$} \\
\hline & $\begin{array}{l}\text { Second-degree } \\
\text { relative with } \\
\text { psoriasis }\end{array}$ & \multicolumn{2}{|l|}{$34(41 \%)$} \\
\hline \multirow{6}{*}{$\begin{array}{c}\text { Potential } \\
\text { trigger } n,(\%)\end{array}$} & Infection & \multicolumn{2}{|l|}{$22(27 \%)$} \\
\hline & Trauma & \multicolumn{2}{|l|}{$12(14 \%)$} \\
\hline & Vaccination & \multicolumn{2}{|l|}{$7(8 \%)$} \\
\hline & Insolation & \multicolumn{2}{|l|}{$5(6 \%)$} \\
\hline & Stress & \multicolumn{2}{|l|}{$3(4 \%)$} \\
\hline & Not identified & \multicolumn{2}{|l|}{$34(41 \%)$} \\
\hline
\end{tabular}

In $18(30 \%)$ children with definite JPsA, skin lesions presented as the first sign of the disease, joint damage in these patients developed after $3.5 \pm 2$ years. In 29 (49\%) patients' articular syndrome was observed on the onset with subsequent skin manifestations after $5.3 \pm 3$ years. Fourteen $(23 \%)$ children with definite JPsA had simultaneous debut of skin and articular syndromes.
Vancouver criteria. The clinical and demographic characteristics are presented in Table 1. 
Figure 1. Vulgar psoriasis in patient with JpsA

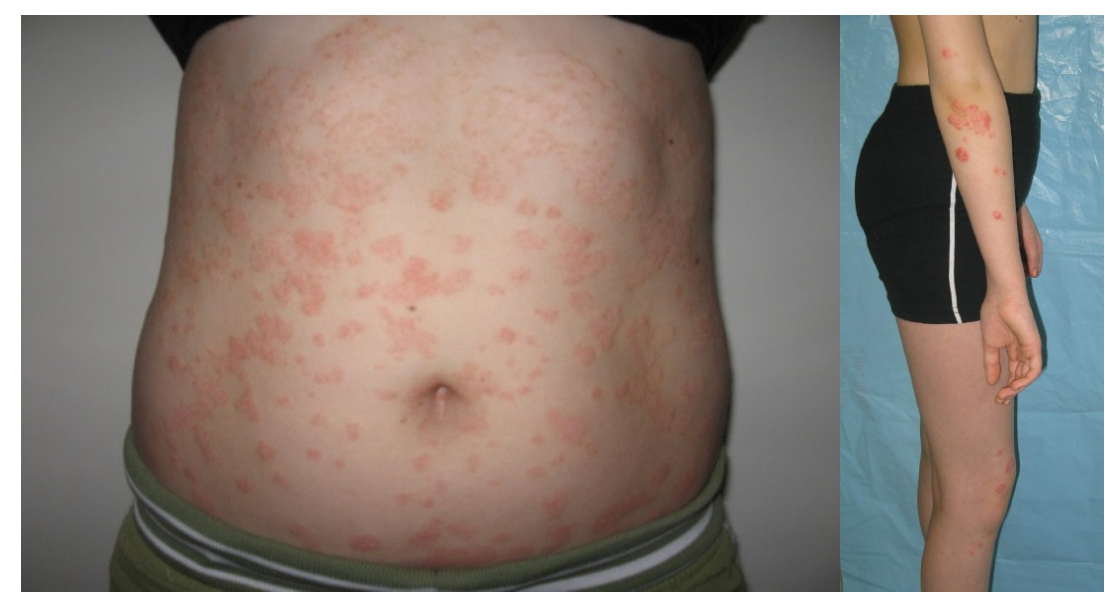

Articular syndrome in the onset of the disease was represented by oligoarticular arthritis in $58(70 \%)$ patients, in 16 $(19 \%)$ children - symmetric rheumatoid-like arthritis, and in $11(13 \%)$ - spondylitis. The most commonly involved joints at both presentation and during the course of the disease were the knee (41\%), ankle (31\%), and small joints of the hands $(29 \%)$. During course of the disease, the articular syndrome transformed with symmetric rheumatoid-like arthritis prevalence.

All joint groups in PsA may be involved in the pathological process. However, knee joints, ankles, and interphalangeal joints are more often affected $(41.0 \%, 31.3 \%, 28.9 \%$, respectively) (Table 2, Figure 4).

Table 2. Joint disease incidence in PsA children $(n=85)$

\begin{tabular}{|l|c|c|}
\hline \multicolumn{1}{|c|}{ Affected joints } & Absolute number, $\mathbf{n}$ & $\mathbf{\%}$ \\
\hline Axial skeleton (cervical, thoracic, lumbar spine sections) & 6 & 10,8 \\
\hline Temporomandibular joint & 1 & 1,2 \\
\hline Shoulder joints & 6 & 7,2 \\
\hline Elbow joints & 9 & 10,8 \\
\hline Wrist joints & 10 & 12,1 \\
\hline Small joints of the hands & 24 & 28,9 \\
\hline Hip joints & 8 & 9,6 \\
\hline Knee joints & 34 & 41,0 \\
\hline Ankle joints & 26 & 31,3 \\
\hline Small joints of the feet & 15 & 18,1 \\
\hline Enthesopathies & 4 & 4,8 \\
\hline
\end{tabular}

Figure 2. Joint damage in JpsA

Mutilans arthritis

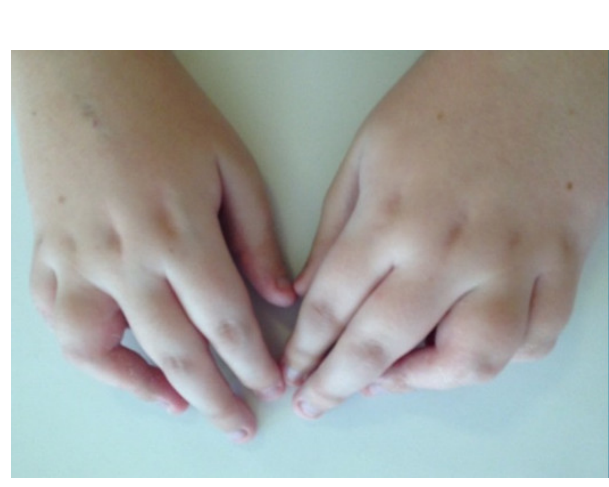

Arthritis of the distal interphalangeal joints. Psoriatic damage to the nail plates

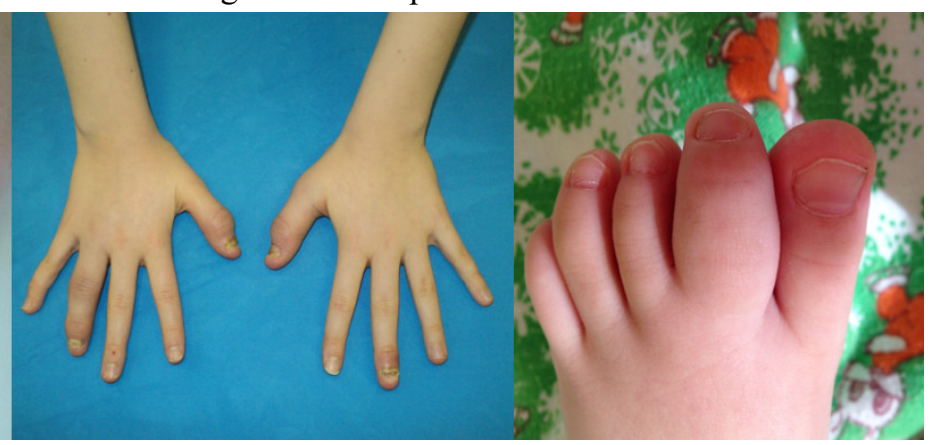


According to our data, the clinical picture of PsA turned out to be variable. In 40 (47\%) children, the disease was characterized by high laboratory and clinical activity. Exacerbations of articular and skin syndromes were noted up to 5-6 times a year. In $45(53 \%)$ patients, on the contrary, the process was easy, there was a positive effect from the ongoing anti-rheumatic therapy.

According to the results of the X-ray examination, in the active period of the disease, $40(45 \%)$ patients had the I radiological stage according to Steinbroker, in 44 (53\%) the IIIIV radiological stages.

It should be noted that in all patients, periarticular osteoporosis was expressed, which is not characteristic of PsA.

\section{DISCUSSION}

Despite the current experience and knowledge in the field of PsA, the etiology and pathogenesis are still largely unclear. Environmental factors, including infection, trauma, stress, only trigger factors in the development of PsA in genetically predisposed people.

So, according to the results of our study in most cases $(41 \%)$, the potential trigger could not be established. A hereditary predisposition to the development of psoriasis and PsA are noted: it is known that more than $40 \%$ of patients have a family history of psoriasis in relatives of the 1 st degree of kinship. According to our data, a family history of psoriasis among relatives of the 1 st degree of kinship was observed in $26 \%$ of children, 2 nd degree of kinship - in $41 \%$ of children. Girls predominate in the sexual distribution, which is consistent with literature $(6,7,8)$. However, two peaks of morbidity at an early age and adolescence described in the literature are not traced by us. In childhood, according to a few studies, in $50 \%$ of cases, arthritis precedes the appearance of psoriasis $(9,10)$. So, according to our data, in $48.0 \%$ of children, articular syndrome preceded psoriasis. In children with JPsA, asymmetric oligoarthritis is more often observed at the onset of the disease $(9,10,11,12)$. Among the children we observed in the onset of the disease, asymmetric oligoarthritis was recorded in $69 \%$ of children. During the course of the disease, a transformation of the articular syndrome was observed with rheumatoid arthritis prevailing (46.6\%). The most common clinical form of psoriasis was plaque psoriasis $(71.2 \%)$, which is consistent with published data. $(13,14,15)$. Much less often than in the described literature, an isolated lesion of the nail plates was found (5\% versus $20-50 \%$ ) (15). In $40-60 \%$ of patients, biomarkers of inflammation (ESR and CRP) remain normal (16). In our study, in $20 \%$ of children, the disease proceeded without activity. The X-ray picture in PsA is characterized by features: narrowing of the joint gap, bone remodulation (resorption of terminal phalanges, large eccentric erosion, osteolysis), bone proliferation (marginal bone growths, periostitis, enthesophytes, bone ankylosis), asymmetric bilateral or unilateral spondylitis, paravertebral ossification and marginal syndesmophytes (17). According to our data, 53\% of patients had the III-IV radiological stages, 47\%) patients had the I radiological stage according to Steinbroker. Periarticular osteoporosis has been described in all children with JPsA, which is not characteristic of JPsA (18).

\section{CONCLUSION}

The clinical picture of JPsA is variable. Most patients with JPsA do not have a chronological relationship between skin and joint damage. The most common form of psoriasis is plaque psoriasis. At the onset of the disease, asymmetric oligoarthritis prevails, followed by transformation with a predominance of rheumatoid-like arthritis. Thus, children with JPsA require the joint supervision of a rheumatologist and a dermatologist.

\section{CONFLICT OF INTEREST}

None.

\section{FUNDING}

None.

\section{LITERATURE}

1. Veale DJ, Fearon U. The pathogenesis of psoriatic arthritis. Lancet. 2018;391 (10136):2273-2284. DOI: 10.1016/S0140-6736(18)30830-4

2. Prakken BJ, Martini A, Malattia C. Juvenile idiopathic arthritis: pathogenesis and clinical aspects. EULAR Textbook on Paediatric Rheumatology. Amsterdam, 2018.

3. Sevostyanov VK, Zholobova ES, Melik-Huseynov DV. Structure of juvenile idiopathic arthritis according to the register of children with rheumatic diseases in Moscow. RMJ. 2017;1:6-10. (In Russian).

4. Petty R, Southwood TR, Manners P, Baum J, Glass DN, Goldenberg J, et al. International League of Associations for Rheumatology classification of juvenile idiopathic arthritis: second revision, Edmonton, 2001. The Journal of Rheumatology. 2004; 31 (2): 390-392.

5. Southwood TR, Petty RE, Malleson PN, Delgado EA, Hunt DW, Wood B, et al. Psoriatic arthritis in children. Arthritis and Rheumatism. 1989; 32 (8): 1007-1013. DOI: 10.1002/anr.1780320810

6. Stoll ML, Nigrovic PA. Subpopulations within juvenile psoriatic arthritis: A review of the literature. Clinical \& Developmental Immunology, June-December 2006; 13(2-4): 377-380,

7. Stoll ML, Zurakowski D, Nigrovic LE, Nichols DP, Sundel RP, Nigrovic PA. 2006. Patients with juvenile psoriatic arthritis comprise two distinct populations. Arthritis Rheum 54:3564-3572.

8. Stoll ML, Elizabeth DM. Psoriatic Arthritis in Childhood: A Commentary on the Controversy. Clin Immunol. 2020 May; 214:108396 doi: 10.1016/j.clim. 2020.108396 . 
9. Prakken BJ, Martini A, Malattia C. Juvenile idiopathic arthritis: pathogenesis and clinical aspects. EULAR Textbook on Paediatric Rheumatology. Amsterdam, 2018; 24.

10. Чебышева СН, Жолобова ЕС, Алексанян КВ, Мелешкина АВ, Геппе НА Псориатический артрит у детей: особенности клинической картины. Georgian Medical News. 2019. 4 (289): 73-77

11. Southwood TR, Petty RE, Malleson PN, Delgado EA, Hunt DW, Wood B, et al. Psoriatic arthritis in children. Arthritis and Rheumatism. 1989; 32 (8): 1007-1013. doi: 10.1002/anr.1780320810

12. Moll JMH., Wright V. Psoriatic arthritis. Semin. Arthr. Rheum., 1973,3,55- 78

13. Boehncke WH, Schon MP. Psoriasis. Lancet. 2015;386(9997):983-94

14. Silverberg N.B. Update on pediatric psoriasis, part 1: clinical features and demographics. Cutis. 2010; 86(3):118-24
15. Relvas, M, Torres T. Pediatric Psoriasis. American Journal of Clinical Dermatology. 2017; 8(6), 797-811. doi:10.1007/s40257-017-0294-9

16. Коротаева ТВ, Корсакова ЮЛ, Логинова ЕЮ, Губарь $\mathrm{EE}$, Чамурлиева МН. Псориатический артрит. Клинические рекомендации по диагностике и лечению. Современная ревматология. 2018;12(2):22-35

17. Chandran V, Barrett J, Schentag NC, et al. Axial Psoriatic Arthritis: update on a longterm prospective study. J Rheumatol. 2009;36;2744-50. DOI: http://dx.doi.org/ $10.3899 /$ jrheum.090412

18. Логинова ЕЮ, Коротаева ТВ, Смирнов АВ и др. Особенности поражения осевого скелета при раннем псориатическом артрите (исследование РЕМАРКА). Научно-практическая ревматология. 2016;54 (Прил. 1):15-9. doi: 10.14412/1995-4484-2016-1S-15-19 